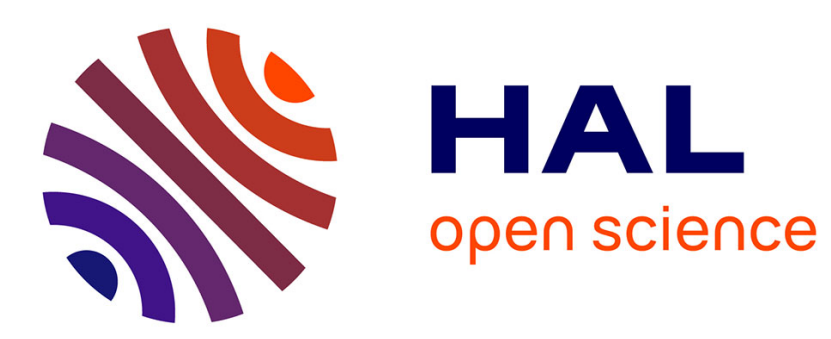

\title{
CAPACITANCE TRANSIENT SPECTROSCOPY (DLTS) OF EXTENDED DEFECTS IN SEMICONDUCTORS
}

\author{
U. Gnauert, J. Kronewitz, M. Seibt, W. Schröter
}

\section{- To cite this version:}

U. Gnauert, J. Kronewitz, M. Seibt, W. Schröter. CAPACITANCE TRANSIENT SPECTROSCOPY (DLTS) OF EXTENDED DEFECTS IN SEMICONDUCTORS. Journal de Physique IV Proceedings, 1991, 01 (C6), pp.C6-335-C6-336. 10.1051/.jp4:1991649 • jpa-00250735

\section{HAL Id: jpa-00250735 https://hal.science/jpa-00250735}

Submitted on 1 Jan 1991

HAL is a multi-disciplinary open access archive for the deposit and dissemination of scientific research documents, whether they are published or not. The documents may come from teaching and research institutions in France or abroad, or from public or private research centers.
L'archive ouverte pluridisciplinaire HAL, est destinée au dépôt et à la diffusion de documents scientifiques de niveau recherche, publiés ou non, émanant des établissements d'enseignement et de recherche français ou étrangers, des laboratoires publics ou privés. 


\section{CAPACITANCE TRANSIENT SPECTROSCOPY (DLTS) OF EXTENDED DEFECTS IN SEMICONDUCTORS}

U. GNAUERT, J. KRONEWITZ, M. SEIBT and W. SCHROTER

IV. Physikalisches Institut der Universität Göttingen, Bunsenstr. 11-15, D-3400 Göttingen and Sonderforschungsbereich 345 Göttingen, Germany

Deep level transient spectra of extended defects show significant differences from those of point defect. Experimentally well established are the logarithmic capture characteristics, i.e. $C_{m} \sim \ln \left(t_{p}\right)\left(C_{m}:\right.$ line amplitude, $t_{p}:$ filling pulse length), and a significant line broadening, which is strongly asymmetric in some cases, nearly symmetric in others. As has been shown by several authors, the unusual capture law is associated with the existence of a capture barrier, whose height varies with the charge of the extended defect. But it has been also shown, that this barrier is not responsible for the line broadening.

Recent experiments have shown up a significant difference in the DLTS characteristics of different kinds of extended defects. The temperature $\mathrm{T}_{\mathrm{m}} \mathrm{x}$ of the line maximum may (I) either stay unchanged with variation of $t_{p}$ or (II) may decrease. The behaviour (I) is well known from the first studies of dislocations in silicon, while case (II), i.e. a decreasing $T_{m a x}$ with increasing $t_{p}$ has been found recently by us for thin NiSiz-platelets. The cases (I) and (II) may be also recognized from typical differences in the line shape.

Using computer simulations we show in this work that the line shape and the $T_{m a x}\left(t_{p}\right)$-relation is strongly influenced by two properties of the extended defect: (1) its density of states, and (2) the carrier exchange rate rxc within it. We have studied in some detail the two limiting cases that (2a) rxc is large compared to electron capture rate at the defect, and that (2b) rxc small 
compared to the electron emission rate from the defect.

In the first case the occupation of the extended defect at any time during emission can be approximated by one occupation probability $f$ or one quasi-Fermi level $E_{Q F}$. In the rate equation the emission term is an integral taken over the product of the defect density of states $N_{d}(E)$, their occupation probabilty $f(E)$ and the emission rate $e_{n}(E)$. It turns out that in this case (2a) the DLTS-line maximum shifts with $t_{p}$.

In the second case the emission of any state $E_{i}$ of the extended defect occurs independently of all the others and $f\left(E_{1}\right)$ is obtained as solution of the rate equation for state $i$. The total number of electrons emitted during the small time interval dt is obtained as a sum over all $i$ of the changes of $f\left(E_{1}\right)$ during the time interval dt considered. The simulation shows that in this case (2b) the line maximum $T_{m a x}$ does not shift with $t_{p}$.

The results of the simulation establish a clear relation between the physical criteria (2a) and (2b) and the experimentally established cases (I) and (II).

Case (2a) is shown to apply to the DLTS of small Nisiz-platelets in silicon, whose line shape is consistent with the density of states of a two-dimensional system. Case $(2 b)$ is observed in the DLTS of edge-type dislocations in silicon. A possible density of states in this case results from a point defect cloud in the compression field of the dislocation. 